\title{
Income Smoothing, Idiosyncratic Risk \& CEO Turnover
}

\author{
Xingguo Zhang \\ School of Finance, Shanghai University of Finance and Economics, Shanghai, China \\ Email: zhangxingguo16@163.com
}

Received 13 December 2015; accepted 2 February 2016; published 5 February 2016

Copyright (C 2016 by author and Scientific Research Publishing Inc.

This work is licensed under the Creative Commons Attribution International License (CC BY). http://creativecommons.org/licenses/by/4.0/

(c) (i) Open Access

\begin{abstract}
The article discussed the feasibility from the idiosyncratic risk point of view that CEO enhances the stability of its position by income smoothing. Taking the data of A-share companies listed in Shanghai Stock Exchange and Shenzhen Stock Exchange between 2005 and 2011, the article examined the direct influence of income smoothing upon change of CEO and its indirect influence upon change of CEO by influencing idiosyncratic risks. The article found that the increase of the income smoothing degree would significantly decrease the probability of change of CEO, while the increase of idiosyncratic risks would significantly increase the probability of change of CEO. In addition, the influence of income smoothing upon change of CEO, to a great extent, is realized by influencing idiosyncratic risks. The evidences used in the article show that one of CEO's major motives to perform income smoothing is to safeguard its position.
\end{abstract}

\section{Keywords}

Income Smoothing, Idiosyncratic Risk, CEO Turnover

\section{Introduction}

It is a very common phenomenon that the managers of foreign and domestic enterprises use accounting rules to manage enterprise earnings so that the change of income in financial statements is consistent with their intention. The motivation of enterprise manager to manage enterprise earnings has always been a focus for academic research. Earnings management refers to the behavior that enterprise manager controls accounting earnings disclosed to the public without violation of accounting standards in order to maximize the interests of enterprise manager's own, instead of to improve corporate value. The purpose of earnings management is usually to smooth income, i.e., to keep the earnings of various periods relatively stable and avoid sharp fluctuation of enterprise income. However, income smoothing may decrease corporate value according to Rountree [1]. Income 
smoothing at the cost of damaging the whole interests of shareholders should be restricted, regulator should perfect the existing accounting system and require enterprises to enhance information disclosure to better protect the interests of investors. Loomis quoted the view of the CEO of a Global 500 company that the top priority of management is to smooth our income. Graham, et al. [2] found that among the managers of the 401 respondents, $96 \%$ of them admitted they would manage earnings to smooth income. It is also a widespread phenomenon that domestic enterprises manage their earnings, which the academic circle has been extensively studied (Lu Jianqiao [3]; Sun Zhen \& Wang Yuetang [4]; Chen Xiao \& Dai Cuiyu, [5]).

There are two types of studies related to this article: 1) studies on the relationship between income smoothing and CEO turnover; and 2) studies on idiosyncratic risks.

In respect of studies on the relationship between income smoothing and CEO turnover, Gordon [6] pointed out that the utility of CEO increases as job security increases, which gives CEO motivation to smooth income to enhance its job security and increase its utility. Fudenberg and Tirole [7] theoretically demonstrated that in a state of equilibrium, the degree of income smoothing will rise when enterprise manager pays more attention to its job security.

In respect of empirical tests, DeFond and Park [8] found that CEO will smooth income by increasing (decreasing) current earnings through accounts receivable to decrease the possibility of dismissal when its current performance is bad (good) and is expected to be good (bad) in the next period. Ahmed et al. [9] found that the more enterprise manager pays attention to its job security, the higher the degree of income smoothing is. Graham [2] believed that enterprise manager will smooth income for the sake of its career instead of short term earnings. Charfeddine and Bouaine [10] empirically studied the relationship between income smoothing and CEO term of office based on the data of 271 U.S. companies between 2003 and 2007 and found that CEO will smooth income for the sake of its job security and income smoothing is helpful for prolonging its term of office.

However, domestic scholars placed extra emphasis on research on the motivation of earnings management in respect of avoiding being delisted, improving corporate performance, corporate governance and obtaining more remuneration, but there are few direct and full researches on the motivation of earnings management for job security or decreasing the probability of being dismissed.

By overhauling the distribution of return on equity of listed companies, Sun Zheng and Wang Yuetang (1999) [4] found that earnings management of listed companies mainly reflects in allotment phenomenon, meager profit phenomenon and significant loss phenomenon. Xue Shuang [11] found through empirical test on samples of A-share listed companies suffering loss between 1995 and 2000 that earnings management prevails among the loss-making companies in various industries. Wei Tao studied the behavior that Chinese listed companies used non-recurring profit or loss to manage earnings and found that both loss-making companies and profit-making companies depend on non-recurring profit or loss at the time of earnings management. In terms of motivation of earnings management, loss-making companies mainly want to stop loss and avoid loss or something like that, while profit-making companies want to smooth profit and avoid profit decrease. Yuan Chunyun [12] found through empirical research on the samples of listed companies between 2002 and 2004 that all outgoing executives improve short term earnings by enlarging non-recurring profit or loss. Su Dongwei and Lin Dapang [13] studied the effect of stock option incentive on corporate governance in terms of earnings management and found that earnings management significantly increases the probability that CEO will exercise its option so that stock option incentive has adverse effect on corporate governance.

There is literature on idiosyncratic risk which is closely related to the study of this article in two aspects. Some studies are about the relationship between income smoothing and idiosyncratic risk. The other studies are about the relationship between CEO turnover and idiosyncratic risk. Idiosyncratic risk refers to the risk specific to a company that causes fluctuation of the stock price of this company assuming that market is effective and all the factors that affect the stock returns can be priced.

Let's discuss the first aspect of studies first. Income smoothing may decrease the risk at company level [14], the signals sent by income smoothing can decrease the uncertainty of future earnings [15], and this uncertainty has positive correlation with fluctuation of stock yield. And the higher the degree of income smoothing is, the more easily future income stream can be forecasted, the possibility that bad news occurs in the future will decrease. The above said studies give indirect evidences that income smoothing has negative correlation with idiosyncratic risk. Lu Yao and Shen Xiaoli [16] found that after relevant characteristics of a company, the company and the fixed effect of time have been controlled, the degree of earnings management of the company has remarkable negative correlation with the content of information at company level in its stock price. In that ar- 
ticle, idiosyncratic risk was used to measure the content of information at company level in stock price. This indirectly indicates that the degree of earnings management has negative correlation with idiosyncratic risk. Rajgopal and Venkatachalam [17] believed that the rise of idiosyncratic risk can partially attribute to the deterioration of earning quality. They also empirically tested idiosyncratic risk and analyst forecast dispersion degree (analyst forecast dispersion degree refers to the degree of difference among analyst forecasted future earnings) and found that idiosyncratic risk has positive correlation with analyst forecast dispersion degree. Markarian et al. [18] believed that analyst forecast dispersion degree has negative correlation with income smoothing so that idiosyncratic risk should have negative correlation with income smoothing. Through empirical tests, it is found that income smoothing has adverse influence upon idiosyncratic risk.

Among those studies about the relationship between CEO turnover and idiosyncratic risk, Meulbroek [19] believes that since a manager who avoids risks is only compensated for systematic risk although he bears the total risks of a company, the manager has motivation to decrease idiosyncratic risk. The economic modeling and empirical analysis made by Bushman [20] show that on the premise that performance is controlled, the rise of idiosyncratic risk increases the probability that CEO will be dismissed. Domestic scholars haven't directly and fully studied the relationship between CEO turnover and idiosyncratic risk. Ye Ling and Li Xinhe [21] found that the declining performance of a company will result in CEO turnover, and the possibility of CEO turnover in nonstate-owned listed companies is lower than in state-owned listed companies. In case of performance improvement after CEO turnover, the performance improvement of a state-owned listed company is less than that of a non-state-owned listed company. If it is believed that declining performance will bring rise of idiosyncratic risk, it can be believed indirectly that idiosyncratic risk has positive correlation with CEO turnover. But this opinion still lacks of direct evidence.

This article is helpful for understanding the direct influence of income smoothing upon CEO turnover. Consistent with many existing studies, this article found that income smoothing will decrease the probability of CEO turnover. This article is also helpful for understanding the direct influence of income smoothing upon idiosyncratic risk. This article found that income smoothing will decrease idiosyncratic risk. This finding is revealing for studying the role of idiosyncratic risk in pricing. This article is also helpful for understanding the indirect influence of income smoothing upon CEO turnover. This article found that a company manager can decrease idiosyncratic risk by income smoothing so as to decrease the probability of dismissal. The evidences of this article show that one of the important motivation of CEO to smooth income is to keep its own position.

\section{Theoretical Analysis and Research Hypothesis}

This article tests two propositions: 1) how income smoothing directly influences CEO's job security, and 2) how income smoothing indirectly influences CEO's job security through idiosyncratic risk.

\subsection{Income Smoothing and CEO Turnover}

Gordon [6] pointed out that the objective of company managers is to maximize their own utility. Manager's utility increases with the rise of job security degree, level and growth rate of manager's income, company scale and company growth rate. The achievement of manager's objective partially depends on the satisfaction of shareholders with company performance, i.e., the more the shareholders are satisfied with company performance, the more manager's job security is stable and the higher the income is, and the utility rises. However, the marginal satisfaction of shareholders with company performance is descending. In other words, when company performance is good, the improvement of shareholder satisfaction by a certain amount of increase in earnings is unobvious, while when company performance is bad, the same amount of increase in earnings can effectively improve shareholder satisfaction, which is helpful for improving manager's job security. Based on this, company managers have motivation to use accounting rules to smooth income and growth rate of earnings in order to better keep their position.

What benefits will be brought to company managers when income is smoothed by decreasing current earnings? High earnings will result in rise of dividend, while the marginal utility of shareholder satisfaction with dividend drops gradually. Therefore, when earnings are high, shareholder satisfaction with dividend has been very high, and the utility of more dividend distribution will be unobvious. When earnings are poor, shareholder satisfaction with dividend is low, and the utility of more dividend distribution will be more obvious. By transferring some of the earnings of high earnings period to low earnings period, dividend distribution is smoothed while income is 
smoothed so that the overall shareholder satisfaction with company manager is improved.

Fudenberg and Tirole [7] pointed out that in a state of equilibrium, the higher the degree of income smoothing is, the lower the probability that company managers are dismissed is. This conclusion is based on the following three hypothesis: 1) company managers can obtain utility from non-monetary private benefit; 2) company will not promise a long term incentive contract, which means that when company performance is bad, company managers will be dismissed; and 3) when shareholders assess managers' performance, in contrast to past earnings, current earnings is of more reference value.

The first two hypotheses mean that company managers have motivation to increase current earnings and reduce the risk of being dismissed in short term by transferring future earnings to current ones. And this motivation will be enhanced with the decrease in company's current performance. The third hypothesis means that company managers have motivation to transfer part of current earnings, if current earnings are good, to a future period the performance of which is bad in order to decrease the probability of being dismissed. This is because company managers are not worried about being dismissed when company performance is good, while they are worried about being dismissed when company performance is bad. Therefore, company managers have motivation to hide the earnings when company performance is good to respond to the situation that future performance is bad in order to prolong their term of office.

Under the pressure of labor market and M\&A market, company managers will hope to keep their position. If a company manager is forced to resign, its reputation will be damaged, which will increase its difficulty in finding a satisfactory job. In addition, M\&A market will pay close attention to the performance of company managers. It seems that companies with bad performance are more likely to be acquired. Scott [22] pointed out that the higher shareholder dissatisfaction with managers of a company is, the higher the possibility that the company is acquired is. When a company is acquired, the managers of the company will generally be replaced.

In short, company managers have motivation to keep their position, avoid being dismissed or decrease the probability of being dismissed in order to enhance manager's utility. That company managers use accounting rules to smooth income can improve the overall shareholder satisfaction with company managers, especially when the actual company performance is relatively bad, and achieve the objective to reduce the probability of being dismissed and enhance manager's utility. Based on this, this article proposes the following hypothesis:

Hypothesis 1: income smoothing will obviously reduce the possibility of CEO turnover. The higher the degree of income smoothing is, the lower the possibility of CEO turnover is; the lower the degree of income smoothing is, the higher the possibility of CEO turnover is.

\subsection{Income Smoothing, Idiosyncratic Risk and CEO Turnover}

\subsubsection{Income Smoothing and Idiosyncratic Risk}

Earnings unnecessarily reflect the true state of operation of a company. Earnings management will result in less transparency of information in respect of earnings. The deterioration of earnings will bring differentiation of investors on company prospect. Empirical tests found that idiosyncratic risk has positive correlation with analyst forecast dispersion degree [17]. The signal sent by income smoothing can reduce the uncertainty of future earnings [15], and make it easier to forecast future income stream, which means that income smoothing has negative correlation with analyst forecast dispersion degree, i.e., idiosyncratic risk should have negative correlation with income smoothing [18]. Therefore, the second hypothesis can be proposed:

Hypothesis 2: Income smoothing will reduce idiosyncratic risk. The lower the degree of income smoothing is, the higher idiosyncratic risk is; the higher the degree of income smoothing is, the lower idiosyncratic risk is.

\subsubsection{Idiosyncratic Risk and CEO Turnover}

Meulbroek [19] believes that when company managers are granted share incentive, their valuation of shares will be lower than market valuation. This is because the market price of a stock only depends on the systematic risk which a company is faced with. Idiosyncratic risk is not priced because it can be avoided by constructing a portfolio. However, the shares granted to managers are only those in the company they are with, instead of a diversified portfolio, and cannot avoid the idiosyncratic risk of the company. Therefore, managers simultaneously bear both systematic risk and idiosyncratic risk that the company is faced with, while investors of diversified portfolios only bear systematic risk. This is the reason why managers' valuation of shares is lower than market valuation. For this reason, managers have motivation to reduce the company's idiosyncratic risk to improve the 
valuation of shares for managers. Bushman [20] believes that performance fluctuation, just like performance, conveys information on the ability of current CEO. However, performance fluctuation may result from the influence of market factors and cannot fully reflect the ability of CEO to control risk, while idiosyncratic risk of stock yield can reflect the ability of CEO to control risk. The higher idiosyncratic risk is, the weaker the ability of CEO to control risk is and the higher the possibility that CEO will be dismissed is; the lower idiosyncratic risk is, the stronger the ability of CEO to control risk is and the lower the possibility that CEO will be dismissed is. Empirical analysis found that the possibility of CEO turnover increases with the rise of idiosyncratic risk if company performance is under control.

Hypothesis 3: The possibility of CEO turnover increases with the rise of idiosyncratic risk. The higher idiosyncratic risk is, the higher the probability of CEO turnover is; the lower idiosyncratic risk is, the lower the probability of CEO turnover is.

\subsubsection{Income Smoothing, Idiosyncratic Risk and CEO Turnover}

If the earnings of a company fluctuate greatly, it will be harder to forecast future earnings and analyst forecast dispersion degree will be high. Empirical tests show that analyst forecast dispersion degree has positive correlation with idiosyncratic risk [17], while analyst forecast dispersion degree has negative correlation with income smoothing [18]. For this reason, great earnings fluctuation may bring higher idiosyncratic risk. Idiosyncratic risk reflects CEO's unobservable ability to control risk. Greater idiosyncratic risk shows that CEO's ability to control risk is weak so that the probability that board of directors dismisses CEO may increase. Based on this, great earnings fluctuation may increase idiosyncratic risk and further increase the probability that CEO will be dismissed. For this reason, CEO has motivation to decrease idiosyncratic risk by reducing earnings fluctuation, i.e., income smoothing, in order to reduce the probability of being dismissed.

Hypothesis 4: Income smoothing will decrease idiosyncratic risk and further decrease the probability of CEO turnover.

\section{Sample Selection and Empirical Approach}

\subsection{Data}

In this article, the data of the companies listed in Shanghai Stock Exchange and Shenzhen Stock Exchange between 2005 and 2011 are used as research sample. The reason why the data since 2005 are selected is that there is relatively complete statistics in database on institutional investor shareholding proportion data used in this article since 2005. In addition, companies listed for less than 3 years are eliminated in this article. This is because when income smoothing is measured, quarterly financial data of listed companies in the past three years will be used. After listed financial companies and listed companies with incomplete data are eliminated, there are 8361 sample data left. To take into account the outliers among these data, all data are winsorized at $1 \%$ in this article. All data used in this article come from Wind and CSMAR.

\subsection{Variables and Measurement}

\subsubsection{Measurement of Income Smoothing}

Income smoothing refers to the behavior that company managers legally use accounting rules to manage company earnings so that company earnings will be distributed more uniformly in a certain period and the fluctuation earnings in a certain period will be reduced. The index used by Myers and Skinner (1999) and Leuz et al. (2003) are used in this article, and income smoothing is measured using the negative of the correlation coefficient between the change of the accrued items and the change of cash flow from operating activities in the past twelve quarters. The change of accrued items refers to the change value of the accrued items of a certain quarter of this year minus the accrued items of the same quarter in previous year. Myers and Skinner believes that companies usually use accrued items to smooth their cash flow. Therefore, the higher the negative of this correlation is, the higher the degree of income smoothing is. In the following robustness test, the income smoothing measurement method used by Tucker and Zarowin [15] is used in this article to measure the degree of income smoothing, that is, the negative of the correlation between managed earnings and unmanaged earnings. Jones model is used in this article to calculate managed earnings and unmanaged earnings are measured with actual earnings subtracting managed earnings. 


\subsubsection{CEO Turnover}

CEO is the top manager of an enterprise responsible for day to day operations and management. In terms of corporate governance structure of Chinese listed companies, the position corresponding to CEO is general manager. CEO turnover referred to in this article means that an individual holding a title of general manager is dismissed for a reason disclosed or undisclosed. Transfer between general manager and chairman doesn't fall into CEO turnover. This definition is similar to the common practice of other scholars [23]. In the database of Guotai Junan Securities, there are following several explanations on the reasons of general manager turnover: job transfer, retirement, expiration of term of office, change of controlling interest, resignation, dismissal, health problem, personal problem, completion of corporate governance structure, case involvement and other reasons. Following the method used by Shen Yifeng and Chen huyu [23] to classify CEO turnover, in this article, job transfer, expiration of term of office, resignation, dismissal, case involvement and other reasons are regarded as compulsory turnover, while retirement, change of controlling interest, health problem, personal problem and completion of corporate governance structure are regarded as normal turnover. CEO turnover studies in this article is compulsory CEO turnover. Since the chairman of a Chinese listed company is usually appointed by the majority shareholder, and the share concentration is relatively high in China, chairman has considerable power in company operation and often participates in day to day operations and management and will be regarded as the top manager [24]. For this reason, robustness test will be performed on this study with chairman being regarded as CEO later in this article.

\subsubsection{Idiosyncratic Risk}

Idiosyncratic risk reflects the fluctuation of stock yield of a company caused by its specific factors. In this article, the method used by Morck et al. (2000) and Andrew et al. (2006) is followed, the three factors of Fama and French (1992) are regressed using the daily excess earnings of each stock per annum and the degree of fitting R2 will be calculated, then 1-R2 will be used as the idiosyncratic risk of each stock in this year. This measurement method has been common in existing literature.

\subsubsection{Controlled Variables}

The controlled variables used in this article include institutional investor shareholding proportion, company scale, book-to-market ratio, return on total asset, debt ratio, share concentration, fluctuation of cash flow from operating activities. Institutional investor shareholding proportion refers to the proportion of shares in a company held by all institutional investors to total shares of the company. Institutional investor shareholding proportion reflects the information content of share price and has influence on idiosyncratic risk [25]. Garen et al. believes that company scale reflects information asymmetry and has a certain influence on idiosyncratic risk. The logarithms of total assets are used in this article as the measure of company scale. Book-to-market ratio refers to the ratio of book value to market value. A company with a low book-to-market ratio usually has better growth, but its future performance is uncertain, which will result in higher idiosyncratic risk. In this article, return on total assets is measured at the ratio of net profit after deducting non-recurring earnings to total assets. Return of total assets reflects a company's profitability. This article believes that a company with a stronger profitability has lower possibility of general manager turnover. In this article, the ratio of total liabilities to total assets is used to measure a company's debt ratio. This article believes that a company with a high debt ratio is faced with high uncertainty, which will result in higher idiosyncratic risk. This article believes that the higher the share concentration of a company is, the more easily the misconduct of the general manager of the company is punished, and the more possibly the general manager is dismissed when company performance or share performance is bad. In this article, the sum of the shareholding proportions of top 10 shareholders is used to measure share concentration. This article believes that a company with higher fluctuation of cash flow is faced with greater uncertainty in respect of production and its idiosyncratic risk will be higher.

\subsection{Empirical Approach}

This article studies the direct and indirect influence of income smoothing on CEO turnover. The direct influence of income smoothing on CEO turnover is analyzed firstly. After that, this article analyzes whether income smoothing will have indirect influence on CEO turnover by influencing idiosyncratic risk. In this article, probit model is used to test the influence of income smoothing on CEO turnover. The model is detailed as follows: 


$$
C E O T_{i, t}=I N S M_{i, t}+I N S T_{i, t}+R O A_{i, t}+B T M_{i, t}+O C_{i, t}+L E V_{i, t}+T A_{i, t}+D E V_{-} C F O_{i, t}+\delta_{i}+\phi_{i, t}+\varepsilon_{i, t}
$$

when CEO turnover happens in Company $i$ in Period $t$, set equal to 1 ; otherwise set it equal to zero. $I_{N S M_{i, t}}$ and $D E V_{-} C F O_{i, t}$ respectively represents the degree of income smoothing and the fluctuation of cash flow from operating activities of Company $i$ in Period $t-2$, Period $t-1$ and Period $t . I N S T_{i, t}, R O A_{i, t}, B T M_{i, t}, O C_{i, t}, L E V_{i, t}$ and $T A_{i, t}$ respectively represents institutional investor shareholding proportion, return on total assets, book-to-market ratio, share concentration, debt ratio and company scale of Company $i$ in Period $t . \delta_{i}$ and $\Phi_{t}$ respectively represents individual effect and time effect. $\varepsilon_{i, t}$ represents disturbance term.

In order to analyze the indirect influence of income smoothing on CEO turnover, this article regresses the following three models to explain how income smoothing imposes indirect influence on CEO turnover:

$$
\begin{gathered}
I V O L_{i, t}=I N S M_{i, t}+I N S T_{i, t}+R O A_{i, t}+B T M_{i, t}+O C_{i, t}+L E V_{i, t}+T A_{i, t}+D E V_{-} C F O_{i, t}+\delta_{i}+\phi_{i, t}+\varepsilon_{i, t} \\
C E O T_{i, t}=I V O L_{i, t}+I N S T_{i, t}+R O A_{i, t}+B T M_{i, t}+O C_{i, t}+L E V_{i, t}+T A_{i, t}+D E V_{-} C F O_{i, t}+\delta_{i}+\phi_{i, t}+\varepsilon_{i, t} \\
C E O T_{i, t}=I V O L_{i, t}+I N S M_{i, t}+I N S T_{i, t}+R O A_{i, t}+B T M_{i, t}+O C_{i, t}+L E V_{i, t}+T A_{i, t}+D E V_{-} C F O_{i, t}+\delta_{i}+\phi_{i, t}+\varepsilon_{i, t}
\end{gathered}
$$

$I V O L_{i, t}$ represents the idiosyncratic risk of Company $i$ in Period $t$. Considering that CEO turnover may have influence on individual stock and further impose influence on the idiosyncratic risk of individual stock, which will result in influence of endogenous problem, this article uses idiosyncratic risk to regress the one period lagged idiosyncratic risk and controlled variables, and uses the fitted value obtained as explanatory variable for the original model for regression. In addition, CEO may smooth income after observing relatively high idiosyncratic risk so that idiosyncratic risk may result in endogenous problem when income smoothing is regressed. This article uses the one period lagged and two period lagged income smoothing as instrumental variable to perform two stages least square regression. This article will also give the result of three stages least square regression used by Markarian [18] to make the regression result more convincing.

\section{Empirical Test and Result Analysis}

\subsection{Descriptive Statistics}

Table 1 presents the descriptive statistical values of various variables used in this article. In order to grasp the differences of idiosyncratic risk and income smoothing degree between the companies with CEO turnover and those without CEO turnover, this article divides the samples into three parts: the overall sample, samples with CEO turnover and samples without CEO turnover. It can be seen from Table 1 that in contrast to the companies without CEO turnover, the idiosyncratic risk of the companies with CEO turnover is higher, while the degree of income smoothing is lower. In average, in contrast to the companies without CEO turnover, the idiosyncratic risk of the companies with CEO turnover is higher by $2.6 \%$, while the degree of income smoothing is lower by

Table 1. Descriptive statistics.

\begin{tabular}{ccccccccccc}
\hline & \multicolumn{3}{c}{ The overall sample } & \multicolumn{3}{c}{ Samples with CEO turnover } & \multicolumn{3}{c}{ Samples without CEO turnover } \\
\cline { 2 - 10 } Variables & $\begin{array}{c}\text { Sample } \\
\text { number }\end{array}$ & Mean & $\begin{array}{c}\text { Standard } \\
\text { deviation }\end{array}$ & $\begin{array}{c}\text { Sample } \\
\text { number }\end{array}$ & Mean & $\begin{array}{l}\text { Standard } \\
\text { deviation }\end{array}$ & $\begin{array}{c}\text { Sample } \\
\text { number }\end{array}$ & $\begin{array}{c}\text { Mean } \\
\text { Standard } \\
\text { deviation }\end{array}$ \\
\hline IVOL & 8361 & 0.545 & 0.138 & 1,022 & 0.557 & 0.144 & 7339 & 0.543 & 0.137 \\
INSM & 8361 & 0.872 & 0.244 & 1,022 & 0.846 & 0.266 & 7339 & 0.876 & 0.241 \\
INST & 8361 & 30.69 & 24.3 & 1,022 & 26.23 & 23.33 & 7339 & 31.31 & 24.37 \\
ROA & 8361 & 0.0209 & 0.0557 & 1,022 & 0.00686 & 0.0658 & 7339 & 0.0229 & 0.0538 \\
BTM & 8361 & 0.448 & 0.306 & 1,022 & 0.43 & 0.31 & 7339 & 0.45 & 0.306 \\
OC & 8361 & 53.95 & 15.25 & 1,022 & 54.2 & 15.38 & 7339 & 53.92 & 15.23 \\
LEV & 8361 & 0.512 & 0.187 & 1,022 & 0.521 & 0.193 & 7339 & 0.51 & 0.186 \\
TA & 8361 & 21.73 & 1.169 & 1,022 & 21.57 & 1.173 & 7339 & 21.75 & 1.167 \\
DEV_CFO & 8361 & 18.49 & 1.209 & 1,022 & 18.38 & 1.197 & 7339 & 18.51 & 1.21 \\
\hline
\end{tabular}


3.5\%. This shows that idiosyncratic risk and income smoothing degree may have influence on CEO turnover, the influence of idiosyncratic risk is more likely to be negative and the influence of income smoothing is more likely to be positive.

\subsection{Direct Influence of Income Smoothing on CEO Turnover}

It can be seen from Column (1) of Table 2 that the coefficient of income smoothing is -0.152 and its influence on CEO turnover is obviously negative. Therefore, income smoothing is helpful for reducing the probability of CEO turnover. This result is consistent with Hypothesis 1 of this article.

\subsection{Indirect Influence of Income Smoothing on CEO Turnover}

Column (2), (3), (4), (5) and (6) of Table 2 present the regression results of idiosyncratic risk against income smoothing. The first three columns respectively present the regression result of mixed model, random effect model and fixed effect model. Although the result of hausman test shows that it is suitable to use fixed effect model, other regression results as presented also have some reference meaning. It can be seen from the regression results as presented in Column (4) that the coefficient of income smoothing is -0.0206 and it is obviously negative, which shows that the influence of income smoothing on idiosyncratic risk is negative. Considering that the regression may have endogenous problem because CEO may observe high idiosyncratic risk and take income smoothing measures, Column (5) and (6) of Table 2 respectively presents the results of three stages least

Table 2. Regression results of idiosyncratic risk against income smoothing.

\begin{tabular}{|c|c|c|c|c|c|c|}
\hline \multirow{2}{*}{$\begin{array}{l}\text { Explanatory } \\
\text { variable }\end{array}$} & \multirow[t]{2}{*}{ (1) } & \multirow{2}{*}{$\begin{array}{c}(2) \\
\text { IVOL }\end{array}$} & \multirow{2}{*}{$\begin{array}{c}(3) \\
\text { IVOL }\end{array}$} & \multirow{2}{*}{$\begin{array}{c}(4) \\
\text { IVOL }\end{array}$} & \multirow{2}{*}{$\begin{array}{c}\text { (5) } \\
\text { IVOL }\end{array}$} & \multirow{2}{*}{$\begin{array}{c}(6) \\
\text { IVOL }\end{array}$} \\
\hline & & & & & & \\
\hline \multirow[t]{2}{*}{ INSM } & $-0.152^{* *}$ & $-0.0215^{* * *}$ & $-0.0215^{* * *}$ & $-0.0206^{* * *}$ & $-0.360^{* * *}$ & $-0.0531^{* *}$ \\
\hline & $(-1.98)$ & $(-3.74)$ & $(-3.74)$ & $(-3.49)$ & $(-5.04)$ & $(-2.19)$ \\
\hline \multirow[t]{2}{*}{ INST } & $-0.00328^{* * *}$ & $0.000598^{* * *}$ & $0.000598^{* * *}$ & $0.000598^{* * *}$ & $0.000646^{* * *}$ & $0.000699^{* * *}$ \\
\hline & $(-3.03)$ & $(5.00)$ & $(5.00)$ & $(7.01)$ & (8.84) & $(6.22)$ \\
\hline \multirow[t]{2}{*}{ ROA } & $-2.169^{* * *}$ & 0.0125 & 0.0125 & $0.141^{* * *}$ & $-0.119^{*}$ & $0.0965^{* *}$ \\
\hline & $(-5.37)$ & $(0.42)$ & $(0.42)$ & (3.91) & $(-1.92)$ & $(2.31)$ \\
\hline \multirow[t]{2}{*}{ ВTM } & -0.115 & $-0.171^{* * *}$ & $-0.171^{* * *}$ & $-0.183^{* * *}$ & $-0.161^{* * *}$ & $-0.187^{* * *}$ \\
\hline & $(-1.23)$ & $(-14.88)$ & $(-14.88)$ & $(-16.13)$ & $(-13.30)$ & $(-17.64)$ \\
\hline \multirow[t]{2}{*}{ OC } & $0.00331^{* *}$ & $0.0006^{* * *}$ & $0.0006^{* * *}$ & $0.0007^{* *}$ & $0.0007^{* * *}$ & $0.0012^{* * *}$ \\
\hline & (2.33) & (5.93) & (5.93) & $(1.98)$ & (3.22) & $(4.22)$ \\
\hline \multirow[t]{2}{*}{ LEV } & -0.134 & $0.0739^{* * *}$ & $0.0739^{* * *}$ & $0.0928^{* * *}$ & $0.0442^{* * *}$ & $0.0918^{* * *}$ \\
\hline & $(-1.08)$ & $(4.07)$ & $(4.07)$ & $(7.75)$ & (3.33) & $(4.58)$ \\
\hline \multirow[t]{2}{*}{ TA } & $-0.0672^{*}$ & $-0.0199^{* * * *}$ & $-0.0199^{* * *}$ & $-0.0129^{*}$ & $-0.0170^{* *}$ & $-0.0182^{* *}$ \\
\hline & $(-1.69)$ & $(-5.57)$ & $(-5.57)$ & $(-1.92)$ & $(-2.23)$ & $(-2.83)$ \\
\hline \multirow[t]{2}{*}{ DEV_CFO } & $0.0614^{*}$ & $0.00672^{*}$ & $0.00672^{*}$ & 0.000942 & 0.00727 & 0.00561 \\
\hline & (1.78) & (1.88) & (1.88) & $(0.20)$ & (1.11) & (1.30) \\
\hline \multirow[t]{2}{*}{ CONS } & -0.596 & $0.922^{* * *}$ & $0.922^{* * * *}$ & $0.872^{* * *}$ & & $0.869^{* * *}$ \\
\hline & $(-1.28)$ & (11.68) & (11.68) & (6.59) & & (7.41) \\
\hline Industry dummy & YES & YES & YES & YES & YES & YES \\
\hline Year dummy & YES & YES & YES & YES & YES & YES \\
\hline $\mathrm{N}$ & 7728 & 8361 & 8361 & 8361 & 6848 & 5426 \\
\hline
\end{tabular}

Note: values in brackets are t-statistics, ${ }^{*},{ }^{* *},{ }^{* * *}$ stand for $\mathrm{p}<0.1, \mathrm{p}<0.05, \mathrm{p}<0.01$ respectively. 
square regression used by Markarian [18] and the results of instrumental variable regression. It can be seen from the regression results that both the coefficients of income smoothing obtained by two regression means are negative, but vary widely. The coefficients of income smoothing obtained by instrumental variable regression and three stages least square regression are -0.0531 and -0.36 respectively, while there is little difference among the regression coefficients of other explanatory variables, which may stem from the selection differences of instrumental variables.

Table 3 presents the regression results of CEO turnover against idiosyncratic risk. It can be seen from the results as presented in Column (1) that the coefficient of idiosyncratic risk is 0.576 and is obviously positive. This shows that the rise of idiosyncratic risk will increase the probability of CEO turnover, which is adverse to CEO's career development. But this influence remains to be further discussed because it is possible that CEO turnover itself results in the increase in idiosyncratic risk, for which regression may have endogenous problem. In order to mitigate endogenous problem, this article uses idiosyncratic risk to regress the lagged period of idiosyncratic risk and controlled variables to obtain fitted values, and uses CEO turnover to regress fitted values. Column (2) of Table 3 presents the regression results of CEO turnover against fitted values of idiosyncratic risk and it can be found that the coefficient of fitted values is 1.078 and is obviously positive. This result shows that the rise of idiosyncratic risk can increase the probability of CEO turnover. This result is consistent with Hypothesis 3.

The regression results as presented in Table 4 also take into account the influence of income smoothing and idiosyncratic risk on CEO turnover. It can be found from Column (1) of Table 4 that the coefficient of idiosyncratic risk is 0.558 and is obviously positive, the coefficient of income smoothing is -0.139 and is obviously

Table 3. Regression results of CEO turnover against idiosyncratic risk.

\begin{tabular}{|c|c|c|}
\hline \multirow{2}{*}{ Explanatory variable } & (1) & (2) \\
\hline & CEOT & CEOT \\
\hline \multirow[t]{2}{*}{ IVOL } & $0.576^{* * *}$ & $1.078^{* * *}$ \\
\hline & (3.16) & (3.48) \\
\hline \multirow[t]{2}{*}{ INST } & $-0.00375^{* * *}$ & $-0.00390^{* * *}$ \\
\hline & $(-3.45)$ & $(-3.28)$ \\
\hline \multirow[t]{2}{*}{ ROA } & $-2.230^{* * *}$ & $-1.617^{* * *}$ \\
\hline & $(-5.59)$ & $(-3.66)$ \\
\hline \multirow[t]{2}{*}{ BTM } & -0.0348 & -0.0387 \\
\hline & $(-0.35)$ & $(-0.35)$ \\
\hline \multirow[t]{2}{*}{ OC } & $0.00291^{* *}$ & 0.00247 \\
\hline & $(2.05)$ & $(1.54)$ \\
\hline \multirow[t]{2}{*}{ LEV } & -0.183 & -0.172 \\
\hline & $(-1.48)$ & $(-1.27)$ \\
\hline \multirow[t]{2}{*}{ TA } & -0.0414 & -0.0162 \\
\hline & $(-1.06)$ & $(-0.38)$ \\
\hline \multirow[t]{2}{*}{ DEV_CFO } & 0.0450 & 0.0260 \\
\hline & $(1.32)$ & $(0.70)$ \\
\hline \multirow[t]{2}{*}{ CONS } & $-1.318^{* * *}$ & $-1.587^{* * *}$ \\
\hline & $(-2.76)$ & $(-2.72)$ \\
\hline Industry dummy & YES & YES \\
\hline Year dummy & YES & YES \\
\hline $\mathrm{N}$ & 7728 & 6384 \\
\hline
\end{tabular}

Note: values in brackets are t-statistics, ${ }^{*},{ }^{* *},{ }^{* * *}$ stand for $\mathrm{p}<0.1, \mathrm{p}<0.05, \mathrm{p}<0.01$ respectively. 
Table 4. Regression results of CEO turnover against income smoothing and idiosyncratic risk.

\begin{tabular}{|c|c|c|}
\hline & (1) & (2) \\
\hline & CEOT & CEOT \\
\hline \multirow[t]{2}{*}{ IVOL } & $0.558^{* * *}$ & $1.054^{* * *}$ \\
\hline & (3.06) & (3.39) \\
\hline \multirow[t]{2}{*}{ INST } & $-0.00370^{* * *}$ & $-0.00385^{* * *}$ \\
\hline & $(-3.40)$ & $(-3.24)$ \\
\hline \multirow[t]{2}{*}{ INSM } & $-0.139^{*}$ & -0.111 \\
\hline & $(-1.81)$ & $(-1.31)$ \\
\hline \multirow[t]{2}{*}{ ROA } & $-2.106^{* * *}$ & $-1.524^{* * *}$ \\
\hline & $(-5.22)$ & $(-3.42)$ \\
\hline \multirow[t]{2}{*}{ BTM } & -0.0173 & -0.0226 \\
\hline & $(-0.18)$ & $(-0.20)$ \\
\hline \multirow[t]{2}{*}{ OC } & $0.00287^{* *}$ & 0.00243 \\
\hline & (2.02) & (1.52) \\
\hline \multirow[t]{2}{*}{ LEV } & -0.158 & -0.154 \\
\hline & $(-1.27)$ & $(-1.12)$ \\
\hline \multirow[t]{2}{*}{ TA } & -0.0552 & -0.0282 \\
\hline & $(-1.39)$ & $(-0.64)$ \\
\hline \multirow[t]{2}{*}{ DEV_CFO } & 0.0559 & 0.0356 \\
\hline & $(1.62)$ & $(0.93)$ \\
\hline \multirow[t]{2}{*}{ CONS } & $-1.107^{* *}$ & $-1.411^{* *}$ \\
\hline & $(-2.25)$ & $(-2.35)$ \\
\hline Industry dummy & YES & YES \\
\hline Year dummy & YES & YES \\
\hline $\mathrm{N}$ & 7728 & 6384 \\
\hline
\end{tabular}

Note: values in brackets are t-statistics, ${ }^{*},{ }^{* *},{ }^{* * *}$ stand for $\mathrm{p}<0.1, \mathrm{p}<0.05, \mathrm{p}<0.01$ respectively.

negative. However, in contrast to the coefficient of income smoothing as presented in Table 1, the absolute value becomes smaller and significantly decreases, which shows that after introducing idiosyncratic risk, the influence of income smoothing on CEO turnover decreases. Considering that CEO turnover may influence idiosyncratic risk in turn so that this regression will have endogenous problem and error will occur in regression results, this article uses the fitted values of idiosyncratic risk obtained previously as the instrumental variable of idiosyncratic risk to regress and the results as presented in Column (2) of Table 4 are obtained. It can be seen from the regression results that the coefficient of income smoothing is -0.111 , the absolute value of which is smaller than that when idiosyncratic risk is not introduced, and the coefficient becomes unobvious. This shows that the influence of income smoothing on CEO turnover will be embodied through idiosyncratic risk. This result is consistent with Hypothesis 4 of this article.

\section{Robustness Test}

\subsection{Measurement of Income Smoothing}

If the earnings as presented in financial reports are divided into managed earnings and unmanaged earnings, the bigger the correlation coefficient between unmanaged earnings and the earnings as presented in financial reports is, the more it shows that CEO hasn’t performed income smoothing so much. For this reason, Tucker and Zaro- 
win [15] used the negative of the correlation coefficient of managed earnings and unmanaged earnings to measure income smoothing degree: the bigger this value is, the smoother the income is. This article uses this measurement index to examine the influence of income smoothing on idiosyncratic risk again and it can be found that the result as shown in Column (1) of Table 5 is also obviously negative. In addition, by examining the direct influence and indirect influence of income smoothing on CEO turnover again, the results of which are shown in Column (2) and (3) of Table 5, a conclusion consistent with the aforesaid is drawn.

\subsection{CEO Turnover}

CEO is the top manager of an enterprise responsible for day to day operations and management. In terms of corporate governance structure of Chinese listed companies, the position corresponding to CEO is general manager. However, since the chairman of a Chinese listed company is usually appointed by the majority shareholder, and the share concentration is relatively high in China, chairman has considerable power in company operation and often participates in day to day operations and management. For this reason, chairman is regarded as the top manager [24]. Based on this, this article inspects the direct and indirect influence of income smoothing on chairman turnover and the results obtained are shown in Column (4) and (5) of Table 5. When only income smoothing is taken into account, the coefficient of income smoothing is -0.16 and is obvious. This shows that income smoothing has more direct adverse influence on chairman turnover. After introducing idiosyncratic risk, the absolute value of the coefficient of income smoothing becomes smaller and is unobvious. This shows that the direct influence of income smoothing on chairman turnover is diluted.

Table 5. Regression results of robustness test.

\begin{tabular}{|c|c|c|c|c|c|}
\hline & (1) & (2) & (3) & (4) & (5) \\
\hline & IVOL & CEOT & CEOT & COBT & COBT \\
\hline \multirow[t]{2}{*}{ TZ_INSM } & $-0.343^{* *}$ & -1.288 & -0.820 & & \\
\hline & $(-2.24)$ & $(-1.67)$ & $(-0.93)$ & & \\
\hline \multirow[t]{2}{*}{ INSM } & & & & $-0.160^{*}$ & -0.131 \\
\hline & & & & $(-1.94)$ & $(-1.37)$ \\
\hline \multirow[t]{2}{*}{ IVOL } & & & $0.710^{* *}$ & & $0.598^{*}$ \\
\hline & & & (2.13) & & (1.69) \\
\hline \multirow[t]{2}{*}{ BTM } & $-0.169^{* * *}$ & -0.160 & -0.104 & -0.0612 & 0.0243 \\
\hline & $(-20.27)$ & $(-1.49)$ & $(-0.81)$ & $(-0.61)$ & $(0.18)$ \\
\hline \multirow[t]{2}{*}{ OC } & $0.00113^{* * *}$ & $0.00482^{* * *}$ & $0.00435^{* *}$ & $0.00366^{* *}$ & $0.00445^{* *}$ \\
\hline & (8.06) & (3.09) & (2.38) & (2.36) & $(2.27)$ \\
\hline \multirow[t]{2}{*}{ LEV } & $0.0719^{* * *}$ & -0.0839 & -0.152 & -0.0480 & -0.104 \\
\hline & (6.17) & $(-0.61)$ & $(-0.99)$ & $(-0.35)$ & $(-0.63)$ \\
\hline \multirow[t]{2}{*}{ TA } & $-0.0199^{* * *}$ & -0.0409 & 0.0132 & $-0.0798^{*}$ & -0.0493 \\
\hline & $(-5.61)$ & $(-0.96)$ & $(0.27)$ & $(-1.86)$ & $(-0.95)$ \\
\hline \multirow[t]{2}{*}{ DEV_CFO } & $0.00527^{*}$ & 0.0293 & -0.0108 & $0.0881^{* *}$ & 0.0470 \\
\hline & (1.73) & $(0.78)$ & $(-0.26)$ & $(2.35)$ & $(1.05)$ \\
\hline \multirow[t]{2}{*}{ CONS } & $1.229^{* * *}$ & -2.179 & -0.660 & $-1.134^{* *}$ & $-1.342^{*}$ \\
\hline & $(7.74)$ & $(-0.16)$ & $(-0.59)$ & $(-2.27)$ & $(-1.86)$ \\
\hline Industry dummy & YES & YES & YES & YES & YES \\
\hline Year dummy & YES & YES & YES & YES & YES \\
\hline $\mathrm{N}$ & 4177 & 6362 & 5052 & 7728 & 5152 \\
\hline
\end{tabular}

Note: values in brackets are t-statistics, ${ }^{*},{ }^{* *},{ }^{* * *}$ stand for $\mathrm{p}<0.1, \mathrm{p}<0.05, \mathrm{p}<0.01$ respectively. 


\section{Conclusion}

This article studies the direct and indirect influence of income smoothing on CEO turnover and finds that the direct influence of income smoothing on CEO turnover is obvious and will have indirect influence on CEO turnover by influencing idiosyncratic risk. Meanwhile, considering that the governance structures of Chinese listed companies are special and chairman may play the role of CEO in a listed company, the direct and indirect influence of income smoothing on chairman turnover is analyzed and the conclusion consistent with the aforesaid is drawn. In addition, the method used by Tucker and Zarowin [15] is used to reconstruct the measurement index of income smoothing, and the conclusion consistent with the aforesaid can also be drawn. In order to control the endogenous problem that may exist in models, this article adopts two stages least square regression and three stages least square regression used by Markarian [18] and the conclusion consistent with the aforesaid is drawn. Therefore, the conclusion of this article is robust. All in all, the evidences of this article show that one of the important motivations of CEO to perform income smoothing is to keep its position.

\section{Acknowledgements}

This research is supported by National Social Science Fund Project (13 CJL032).

\section{References}

[1] Rountree, B., Weston, J. and Allayannis, G. (2008) Do Investors Value Smooth Performance? Journal of Financial Economics, 3, 237-251. http://dx.doi.org/10.1016/j.jfineco.2008.02.002

[2] Graham, J.R., Harvey, C.R. and Rajgopal, S. (2005) The Economic Implications of Corporate Financial Reporting. Journal of Accounting \& Economics, 40, 3-73. http://dx.doi.org/10.1016/j.jacceco.2005.01.002

[3] Lu, J.Q. (1999) Empirical Research on Earnings Management of Chinese Financially Distressed Listed Company. Accounting Research, Beijing, 9.

[4] Sun, Z. and Wang, Y.T. (2000) An Empirical Study on Resource Allocation and Earnings Manipulation. Journal of Finance and Economics, 4.

[5] Chen, X. and Dai, C.Y. (2004) An Empirical Analysis on the Earnings Management of the A-Share Loss Firms. China Accounting Review.

[6] Gordon, M.J. (1964) Postulates, Principles and Research in Accounting. Accounting Review, 39, 251-263.

[7] Fundenberg, D. and Tirole, J. (1995) A Theory of Income and Dividend Smoothing Based on Incumbency Rents. Journal of Political Economy, 1, 75-93. http://dx.doi.org/10.1086/261976

[8] DeFond, M.L. and Park, C.W. (1997) Smoothing Income in Anticipation of Future Earnings. Journal of Accounting and Economics, 2, 115-139. http://dx.doi.org/10.1016/S0165-4101(97)00004-9

[9] Ahmed, A.S., Zhou, J. and Lobo, G.J. (2006) Job Security and Income Smoothing: An Empirical Test of the Fudenberg and Tirole (1995) Model. SSRN Electronic Journal.

[10] Charfeddine, L. and Bouain, W. (2012) Income Smoothing and CEO Job Security. Information Management \& Business Review, 95-106.

[11] Xue, S. (2003) Earnings Management in Companies Suffering Loss. China Second Empirical Accounting International Symposium.

[12] Yuan, C.Y. (2007) The Empirical Research on the Relationship between Top Management Turnover and Earnings Management. Xiamen University.

[13] Su, D.W. and Lin, D.P. (2010) Share Incentive, Earnings Management and Corporate Governance. Economic Research, Beijing, 11.

[14] Trueman, B. and Titman, S. (1988) An Explanation for Accounting Income Smoothing. Journal of Accounting Research, 3, 127-139. http://dx.doi.org/10.2307/2491184

[15] Tucker, J. and Zarowin, P. (2006) Does Income Smoothing Improve Earnings Informativeness? The Accounting Review, 1, 251-270. http://dx.doi.org/10.2308/accr.2006.81.1.251

[16] Lu, Y. and Shen, X.L. (2011) Information Content of Share Price and Earnings Management: An Empirical Analysis Based on Chinese Stock Market. Financial Research, Beijing, 12.

[17] Bowen, R.M., Rajgopal, S. and Venkatachalam, M. (2008) Accounting Discretion, Corporate Governance, and Firm Performance. Contemporary Accounting Research, 25, 351-405. http://dx.doi.org/10.1506/car.25.2.3

[18] Markarian, G. and Gill-De-Albornoz, B. (2012) Income Smoothing and Idiosyncratic Volatility. SSRN Electronic 
Journal. http://dx.doi.org/10.2139/ssrn.1270826

[19] Meulbroek, L.K. (2001) The Efficiency of Equity-Linked Compensation: Understanding the Full Cost of Awarding Executive Stock Options. Financial Management, 4, 5-44. http://dx.doi.org/10.2307/3666404

[20] Bushman, R., Dai, Z. and Wang, X. (2010) Risk and CEO Turnover. Journal of Financial Economics, 96, $381-398$. http://dx.doi.org/10.1016/j.jfineco.2010.03.001

[21] Ye, L. and Li, X.H. (2011) Listing Corporation CEO Change, Succession Selection and Company Performance. Contemporary Finance, 12, 110-118.

[22] Linn, S. and Zhu, Z. (1997) Aggregate Merger Activity: New Evidence on the Wave Hypothesis. Southern Economic Journal, 64, 130-146. http://dx.doi.org/10.2307/1061043

[23] Shen, Y.F. and Chen, S.Y. (2009) An Empirical Study on Relationship between Overconfidence of Chairman, CEO Turnover and Company Operation Performance. Chinese Journal of Management, 10.

[24] Abdel-Khalik, A.R. (2007) An Empirical Analysis of CEO Risk Aversion and the Propensity to Smooth Earnings Volatility. Journal of Accounting, Auditing and Finance, 2, 201-235.

[25] Lee, D.W. and Liu, M.H. (2011) Does More Information in Stock Price Lead to Greater or Smaller Idiosyncratic Return Volatility? Journal of Banking \& Finance, 5, 1563-1580. http://dx.doi.org/10.1016/j.jbankfin.2010.11.002 